\title{
Bringing Online Learning to Campus: The Hy- bridization of Teaching and Learning at Brigham Young University
}

\author{
Gregory Waddoups \\ Brigham Young University \\ Scott Howell \\ Brigham Young University
}

\begin{abstract}
The primary purpose of Brigham Young University (BYU) is to provide students with a combination of sacred and secular education often described as the "BYU experience." Achieving this purpose is challenged by the rapid growth in Church membership and an enrollment cap of 30,000 students. To address these challenges, BYU sponsors the use of technology to bridge the gap between the increased Church membership and the number of students allowed under the enrollment caps. This institutional case study shows how these challenges have influenced the hybridization of teaching and learning for on campus (resident) and off campus (distance) students. It also describes how BYU has brought distance education to campus, and is beginning to bring campus-based educational practices to distance education.
\end{abstract}

\section{Introduction}

David O. McKay described Brigham Young University as a religious institution established "for the sole purpose of associating science, art, literature, and philosophy with the truths of the Gospel of Jesus Christ" (Richards, 1997). This idea, reflected in the University's Aims, is to provide a spiritually enriched learning environment for all members of the Church of Jesus Christ of Latter-day Saints. Of course, this desire to provide the combination of sacred and secular learning to all members of the Church presents two challenges. First, the rapid growth in Church membership has compromised BYU's ability to serve a significant proportion of the Church membership on campus. Second, the University has placed a cap on enrollments. To address these challenges, BYU sponsors the use of technology to bridge the gap between increased membership and enrollment caps. This goal is the impetus behind distance learning at BYU. The following institutional case study shows how these challenges have influenced 
Bringing Online Learning to Campus: The Hybridization of Teaching and Learning at Brigham Young University

the hybridization of the teaching and learning process for on-campus (resident) and off-campus (distance) students. Further, this study demonstrates how the focus on providing as many students as possible with the "BYU experience" and the drive to maintain quality while improving efficiency is the impetus for the hybridization of education at BYU. Hybridization occurs when on-campus educators adopt distance education technologies and practices, and when distance education organizations adopt/adapt campus-based educational practices. The case study concludes with a discussion of the consequences and the implications of such hybridization.

\section{Literature Review}

Distance education is the use of media to enable time separation and geographical separation of the teaching process from the learning process (Calder, 2000). From the beginning, distance education has been the focus of controversy, with many researchers, administrators, and faculty relegating distance education to an inferior status compared to campus-based educational methods (Feenburg, 1999; Noble, 1999; Turoff, 1998). These debates have focused on technology's inability to effectively bridge the distance between teachers and students and the fear that distance education programs are "diploma mills" (Noble, 1999). Debates concerning distance education have become more intense with the recent availability of computers and the Internet. Many have argued that these technologies can facilitate high-quality interaction between teacher and student (Feenburg, 1999; Hiltz, 1998; Levin, Levin \&Waddoups, 1999; Wegerif, 1999). Traditional universities have adopted practices and technologies from distance education and distance education institutions adopting practices from brick and mortar universities (Arvin et al., 1998; Calvert, 2001; Cookson, 2001). This brief literature review develops a theoretical framework to describe and analyze the convergence associated with the hybridization of education at many institutions including BYU.

One approach to analyzing distance education courses and programs is to focus on the communicative relationship between teacher and student. This approach entails locating distance education courses and programs on a synchronous and asynchronous continuum. This approach focuses on the spatial and temporal relationships between a teacher and students and identifies the various ways in which they use technologies to bridge this distance. For example, a distance education course that uses two-way video is synchronous in nature, allowing students to be spatially distributed, but requiring them to be together at the same time. In this way, synchronous distance education requires a technologically facilitated co-presence between teacher and student. An NEA sponsored study reported that in 1998, 56 percent of all distance education programs used two-way television, which is the most common synchronous distance education method in the U.S.A. (NEA Higher Education Research Center, 2000). More 
Bringing Online Learning to Campus: The Hybridization of Teaching and Learning at Brigham Young University

recently, interactive video conferencing has been used to let teacher and students interact through synchronous chat, whiteboard features, and application sharing, created the possibility of "multi-sensory" learning environments (Peters, 2000). Much like the traditional classroom, synchronous interactions put the teacher in the center of the instructional interaction. This synchronicity may increase the contact between teacher and student; but it also decreases the efficiency and flexibility of distance education. In addition, synchronous distance education potentially duplicates what many regard as the least desirable feature of campus-based education: namely the lecture.

Asynchronous distance education permits students to be separated both in time and place, which maximizes the level of flexibility; however, these instructional methods potentially decrease contact between teacher and student. Correspondence education was the first type of asynchronous distance education in which institutions mailed written material to students; and students completed and returned their assignments for grading. More recently, the use of the Internet and communication technologies such as email and discussion boards has facilitated a higher level of interactivity within the context of asynchronous distance education (Feenburg, 1999; Rossman, 1999; Wegerif, 1999). There is a growing body of research focusing on the value of asynchronous learning networks for distance education students. Wegerif (1999) found that the success of online courses depended upon students feeling like insiders. The skill of the moderator to facilitate open and respectful communication through an asynchronous medium was an important predictor of students developing insider status. Additionally, there have been reports concerning the use of asynchronous learning networks in the context of traditional universities to improve the efficiency and quality of undergraduate education (Arvin, et al., 1998; Bourne, 1998). Focusing on the communicative relationship between teacher and students does not fully account for important issues such as the pedagogical methods and instructional design of the learning environment.

Another approach to the discussion of distance education includes identifying the pedagogical methods and instructional design models associated with a course or program. Two broad pedagogical approaches to distance education include those that focus on the transmission of information, and those distance education methods that focus on interactivity and connectivity. A "transmissive" approach focuses on the delivery of information from teacher to student, whether in a synchronous or asynchronous mode (Bourne, 1998). Peters (2000) described this approach as "heteronomous learning." Technology has been used to increase the efficiency of this form of distance education including the use of television and the Internet. For example, asynchronous transmissive distance education focuses on the delivery of information to students through the postal service, the Internet, videocassettes, or educational television and radio programs. The primary focus of this approach to distance education is efficient delivery of information by the teacher to the student. In contrast, synchronous transmissive distance education duplicates the traditional classroom lecture pri-

International Review of Research in Open and Distance Learning 
Bringing Online Learning to Campus: The Hybridization of Teaching and Learning at Brigham Young University

marily through the use of two-way video technology. Both of these approaches focus on teaching, rather than learning, and locate the instructor at the center of the pedagogical relationship (Bourne, 1998).

A third pedagogical approach is interactive distance education, which focuses on connection, interaction, exploration, and discovery, rather than the transmission of information. Peters (2000) refers to this as "autonomous learning." This model focuses on creating rich environments for student learning rather than efficient ways for teachers to deliver information. The learning environment includes providing students with a flexible array of resources including text, audio, and video in both synchronous and asynchronous modes. Many distance education programs are moving towards a more interactive model focusing on learners and learning rather than teachers and teaching. The interactive distance education model takes what is best about distance education and campus-based education and combines them through the use asynchronous and synchronous technology. This process of convergence has been observed globally among open and distance learning (ODL) institutions (Tait and Mills, 1999; Trindade, Carmo, and Bidarra, 2000). For BYU, the process of convergence is at the core of the hybridization experience, other educational institutions experiencing this kind of hybridization will be particularly interested in this case study.

The following institutional case study describes the ways in which BYU has hybridized distance education, in particular, through bringing online education to campus and bringing campus based practices to distance education. Fundamentally, this kind of hybridization is about challenging traditional academic and institutional boundaries to meet the needs of students. In the case of BYU, Independent Study courses have traditionally been asynchronous and transmissive. As distance education methods came to campus, faculty and administrators became less satisfied with this approach, which has led to the progressive hybridization of on-campus and distance education. The hybridization process is important for many educational institutions as they attempt to find ways to decrease boundaries between their on-campus and off-campus students to meet the needs of a wider number of people. Many institutions that have traditionally separated distance and campus-based education, are trying to find ways to bring distance education to campus (Arvin et al., 1998; Wang et al., 2001) and to create interactive learning environments for distance education students (Bourne, 1998). This convergence is a powerful force within postsecondary educational institutions.

\section{Case Study Research Methods}

Case study research has a long history as a qualitative research method for capturing the complexity of teaching and learning interactions (Merriam, 1987;

International Review of Research in Open and Distance Learning 
Bringing Online Learning to Campus: The Hybridization of Teaching and Learning at Brigham Young University

Stake, 1988; Yin, 1979). According to Merriam (1991), case studies are a method well suited for understanding educational processes. She identifies four elements of the case study that are important for identifying the complexity of the teaching and learning process. First, a case study is "particularistic." By using the term "particularistic," Merriam suggests that case studies focus on a particular "event, program, or phenomenon." The second property of a case study is that it is descriptive of an event or set of processes. This means that the end product of a case study is a "rich, thick description of the phenomenon under study" (p. 12). The third characteristic of the case studies is that it functions as a heuristic to illuminate the phenomenon being studied. The fourth property is that case studies are often inductive, using the data collected and assembled to construct the case. The following institutional case study was conducted through interviews with key stakeholders involved in distance education at BYU; collection and analysis of archival histories; and analysis of data about the mission and purpose of BYU and the place of distance education within BYU. These data were collected and analyzed to construct a narrative account of the emergence, development, and hybridization of distance education at Brigham Young University.

\section{Institutional and Environmental Demands Influ- encing Hybridization}

Brigham Young University (BYU) was established October 1875 in Provo, Utah, U.S.A., as Brigham Young Academy. From the beginning, BYU has maintained the focus of combining sacred and secular education. This focus is based on the relationship between BYU and its sponsoring institution, the Church of Jesus Christ of Latter-day Saints. The Church of Jesus Christ provides funding and leadership for BYU. The BYU president and administration report to Church general authorities, and BYU administrators adapt policies, curriculum, and programs to serve the interests of the Church institution and the wider Church membership. For example, BYU provides an opportunity for future Church leaders, namely the students, to be educated and nurtured so they can return to their homes and strengthen the local Church. According to the institutional mission statement, the purpose of Brigham Young University is to "develop students of faith, intellect, and character who have the skills and the desire to continue learning and to serve others throughout their lives." Accordingly, a BYU education should be intellectually enlarging, character building, spiritually strengthening, and foster lifelong service and learning. Students achieve these institutional Aims through learning in the classroom, participating in weekly extra-curricular devotionals, participating in university student church groups, and developing formal and informal associations with faculty members and students. These formal and informal learning environments are powerful and strengthen the individual members who, in turn, bring strength to the

International Review of Research in Open and Distance Learning 
Bringing Online Learning to Campus: The Hybridization of Teaching and Learning at Brigham Young University

Church of Jesus Christ of Latter-day Saints.

The "BYU experience" is much more than attending class, in fact, it could be considered a whole way of life; a culture of teaching and learning developed through participation within the center and periphery of the university community (Williams, 1961). These are important organizing principles or benchmarks that influence administrative and curriculum decisions and frame the activities of faculty, students, administrators, and support staff at all levels within the BYU community.

Providing the BYU experience for distance learners was an early concern of those involved in the design, development, and delivery of correspondence education. Discussions about distance education at BYU began in the early twentieth century and have focused on the extent to which distance education can provide the experience to Church members and others who are interested, but cannot physically attend BYU, to participate in the BYU experience. Recently, there has been an increased focus on the use of distance education to help meet the educational needs of the growing Church membership. Because of strict enrollment caps presently at 30,000 students, and an ever-increasing pool of applicants, many students who would like to attend BYU cannot.

The enrollment caps limit the number of students who can participate in the BYU experience and impedes the University's ability to serve members of the sponsoring institution. The widening gap between those who wish to attend BYU, but are not able, has led administrators to explore distance education practices and technology to serve more students and to provide them with the BYU experience. The acceptance of distance education, combined with the increased availability of instructional technologies, is the impetus for much of the hybridization of teaching and learning at BYU. Through innovative uses of technology for on-campus courses, the administration hopes to streamline undergraduate education to efficiently serve more on-campus students. For example, large general education courses have been developed that utilize multimedia and communication technologies to increase the efficiency and quality of learning. Similarly, through using the Internet, multimedia, communication technologies, and rapid feedback systems, Independent Study students can have a portion of the BYU experience. In both of these instances, BYU administrators and faculty hope that technology can provide high-quality and efficient learning experiences for both resident and distant students. The effect of BYU's experimentation with distance education is to hybridize education for on-campus and off-campus learners. As the following chronology will show, BYU is early into the hybridization experience; however, many decisions about infrastructure, curriculum, delivery, and assessment remain to be made.

International Review of Research in Open and Distance Learning 
Bringing Online Learning to Campus: The Hybridization of Teaching and Learning at Brigham Young University

\section{Chronology of Events}

In the following chronology, we explain the ways in which technology usage, administrative decisions, the mission and purpose of BYU, the gap between those wanting and able to attend BYU, and the desire to maintain quality and efficiency have resulted in the progressive hybridization of education at BYU. This hybridization process has provided distance-learning opportunities to oncampus students and more interactive learning opportunities to off-campus students. We conclude this chronology by discussing the intended and unintended circumstances of this hybridization process describing the relevance of BYU's experience to other educational institutions.

Distance education began at BYU in 1921, with the establishment of the Bureau of Correspondence to provide opportunities for students to begin home study courses. In 1921, the Bureau of Correspondence accepted responsibility for all work connected with instruction by mail, becoming an agent to help faculty members and students (Henstrom and Oakes, 2001 p. 286). The first correspondence study catalogue was issued November 1, 1922, which listed the courses a student could take and procedures for registering and completing a course. The Bureau of Correspondence primarily served an administrative function; they did not develop University course content, but served as a mediator between faculty and students. A report written in 1922 reported the progress of the Bureau:

In order to systematize the work, various bureaus have been created. The Bureau of Correspondence Education, which handles all of the work connected with instruction by mail. In this work, the bureau only acts as the agent between the faculty member and the student, looking after the registration, publicity, recording of grades and credit, mimeographing and mailing of lessons $\hat{A}$ The present enrollment in this bureau is 255 . Of this number, 120 are missionaries and about 40 are enrolled in the genealogy courses (Henstrom and Oakes, 2001 p. 287).

During the first 25 years of the Bureau of Correspondence, the number of enrollments and course offerings increased progressively.

In 1948, the Bureau of Correspondence was reorganized into the Bureau of Home Study and expanded course offerings into the high school market. At that time, the department took on new breadth and professionalism and a full-time department head was employed for the first time. By 1949, 171 college and seven high school courses were offered with an enrollment of 719 students. Consequently as enrollments and the number of courses increased, the size of the organization increased and the Bureau took more responsibility for designing, developing, and implementing courses. As enrollments increased there was an increasing 
Bringing Online Learning to Campus: The Hybridization of Teaching and Learning at Brigham Young University

need to provide support for faculty and students. For example, during the years 1954-1964, enrollments increased from 1452 to 5,085, which resulted in the need to provide systems for enrollment, registration, lesson processing, and communication between faculty members and students. At this point, a more efficient lesson-processing center and course development and improvement program was instituted to increase the quality and efficiency of the correspondence offerings.

During the period between 1968-1996, enrollments increased from 6,948 to 36,686 and many changes occurred within Bureau of Home Study, not the least of which was being renamed the Department of Independent study in 1978. In 1968, the first instructional designer was hired, indicating the Bureau's desire to take a greater role in the course development process and improve the quality of course offerings. Additionally, the number of enrollments in the high school program rapidly increased. This increase was due to the closing of BYU High School and later an aggressive marketing campaign to sell high school courses to individuals and schools in all regions of the country. As a result, during 1982-1992, high school enrollments tripled from 4,300 to 13,500. According to a history written about this time period: "This increase prompted important and far-reaching changes in student services, registration procedures, and customer service to students and responsible counselors and schools" (Henstrom and Oakes, 2001 p. 323). During this time, Continuing Education constructed a new building to house growing numbers of design, development, and support staff.

As computer technology became more readily available, those responsible for administering Independent Study courses began searching for ways to use technology to improve the efficiency of administering programs and improve the quality of students' learning experience. These changes included bar-coded lessons for easy tracking, computer-generated monthly reports, and a toll-free 800 number for student support, the implementation of a rapid response assignment system called "Speedback," and a grade checking system called "Gradecheck" that let students use the Internet to check a data bank for their grades. For those administering Independent Study courses, technology was seen as a way to improve the efficiency of processing information and improve students' experience in the course. The courses were asynchronous and transmissive with very little interaction between the instructor and student.

As enrollments rose to over 35,000 in 1996, greater demands for student support needs were placed on the system. In response, the Department of Independent Study adopted administrative processes and technologies to improve the quality and efficiency of distance learning. Between 1922 and 1996, the relationship between BYU campus and distance education evolved in a similar manner. Initially, the Bureau of Correspondence served only an administrative function and did not deal with pedagogical issues such as lesson content; this was reserved for the faculty member. Later, the Bureau of Home Study began employing instructional designers to work with faculty allowing them to

International Review of Research in Open and Distance Learning 
Bringing Online Learning to Campus: The Hybridization of Teaching and Learning at Brigham Young University

become much more involved with the actual design, development and delivery of courses. This administrative move increased the quality of the courses and improved the efficiency of delivery, but created distance between on-campus faculty and administrators from the delivery of education to distant learners. Indeed, one of the functions of Independent Study instructional designers was to take responsibility for the design, development, and implementation of the courses. By assuming this level of responsibility, faculty members and campus administrators became more removed from the design and delivery of distance education courses.

\section{7-Current: The Hybrization of Distance Edu- cation.}

In the current phase of development, distance education is beginning influence campus education practices. Web-based university courses emerged at BYU Independent Study in 1997. A small group of instructional designers, programmers, and artists began to develop Independent Study courses in 1997. These were primarily asynchronous and utilized the Web as a distribution medium, coupled with "Speedback" and "Gradecheck" to automate assignments and grading. These high quality courses won several awards including the Helen S. Williams distinguished course award for the development a Health Education and Physical Education 129 in 1998; National Univesity Continuing Education Award for Family History 70, and Communications 101 in 1995. By the end of 1997, Independent Study had developed twenty web-based courses, many of which were converted from paper-based courses and enriched with multi-media and graphics.

In 1998, BYU president Merrill Bateman gave an address that explained how web-based education could increase the efficiency of on-campus education and extend the reach of BYU to off-campus students. This administrative support for expanding the use of online and distance education courses marked an important turning point in the hybridization of education at BYU. President Bateman spoke of ways that technology use would improve campus education, stating:

On-campus education will be streamlined over time with the aid of technology, lectures, data, class assignments, reading materials, exams, and other tutorial materials will be online and on CD-ROM. When used appropriately, new technology has the capacity to reduce lecture time and allow for more discussion groups, seminars, and labs. To the extent that technology increases learning effectiveness, it may increase opportunities for students to be involved in research projects and free up time for faculty research (University Conference Address, 1998).

International Review of Research in Open and Distance Learning 
Bringing Online Learning to Campus: The Hybridization of Teaching and Learning at Brigham Young University

The President continued in this address to articulate ways in which technology might be used to provide learning opportunities for distance education students.

BYU's Division of Continuing Education currently services more than 40,000 students. Most of the courses at present are on paper and available through the mail. During the past year, approximately 20 University course have been converted to the Internet. Plans call for 50 courses on the Internet by the end of 1998, with 300 more courses available within the next five years. The new Internet courses are enriched well beyond their paper predecessors... Hotlinks access video materials that include the professor describing courses objectives, outlining the course, and lecturing. Hotlinks embedded in the course also take students to other Web sitesÂ As the number of Internet courses multiplies, so will the number of students served across the world - at a much reduced cost (University Conference Address, 1998).

Subsequent to this speech, the University administration created and funded the Office of Course Development (OCD) to produce online General Education courses. During this same time, a committee was established to explore ways to centralize and coordinate the learning-technology initiatives for both on-campus and off-campus students. One of the recommendations of this committee was to centralize the development of all Web-based course development into one organization and realign this organization to report to the Vice President over undergraduate education rather than the Vice President of Continuing Education. Based on the committee's recommendation the Center for Instructional Design (CID) was formed in June 1999 by merging three separate entities: the BYU Instructional Technology Center (ITC), the web development team from BYU's Independent Study, and the Office of Course Development (OCD).

The Center for Instructional Design produces and supports the design, development, and implementation of technology-enhanced instruction to on-campus and off- campus students. The CID has evolved over the last two years and now has 26 full time employees and 150 student employees. Among these employees are professional instructional designers, programmers, arts and media production specialists, production managers, and educational evaluators.

The CID develops three types of products related to technology and learning. First, the CID creates Semester Online courses for matriculating on-campus BYU students and for other Church-affiliated schools including BYU Idaho and BYU Hawaii. Second, the CID is responsible for designing university Independent Study online courses intended for students not able to attend the BYU campus. Third, the CID works with faculty on special projects that use instructional technology. The Committee for the Media Arts (CIMA) at BYU juries proposals and funds these projects. Although these projects are distinct, they

International Review of Research in Open and Distance Learning 
Bringing Online Learning to Campus: The Hybridization of Teaching and

inform each other in important ways leading to the progressive hybridization of technology-mediated instruction.

\section{Semester Online}

The Semester Online program is an attempt to provide online educational opportunities for registered BYU students. Because they are on-campus courses, students must complete all course requirements during the semester. President Bateman outlined the following goals of Semester Online courses in his 1998 address. They include:

- Creating efficiencies by using technologies

- Improving education through using technology

- Creating courses and learning objects that can be used to serve and bless the lives of Church members worldwide

Initially, these Semester Online courses were created by enhancing Independent Study Online courses with multimedia, assignment and exam due dates, and plans for limited face-to-face meetings, literally bringing courses intended for off-campus delivery to campus students. During the fall of 1999, thirteen of these courses were offered, with 600 student enrollments. Currently there are 2,500 students enrolled in these courses at BYU Provo and BYU Idaho.

In addition to these retrofitted courses, there has been a massive design and development effort to produce large media-rich, general education courses specifically designed for delivery to on-campus students. These courses will hopefully help students move more efficiently through high-enrolling, required courses that present bottlenecks for students. Additionally, these course re-designs are hopefully improving the quality of these courses, which are often taught in large lecture halls. The first of these courses to be completed was Physical Science 100 (PS 100), which provided a series of multimedia lessons, quizzes, and weekly meetings.

The CID is presently developing an online freshman composition course (English 115 ) that was funded by a $\$ 200,000.00$ grant from the PEW charitable trust. In traditional composition courses, the instructor meets with the entire class three hours a week, then conferences with students as they complete writing assignments. In the revised online version of English 115, the instructor becomes just one of several sources of instruction available to the student: weekly class meetings; instructor conferences; peer-review workshops; mini-classes and tutorials from the Reading and Writing Centers; and a series of multimedia, online lessons that are standard for all sections of the course. This is not a distance 
Bringing Online Learning to Campus: The Hybridization of Teaching and Learning at Brigham Young University

education course, in which the student and instructor are naturally separated, but a course designed for regularly matriculating students, and a radical revision of how a writing program can use technology to redefine instructional space.

In contrast to English 115 and PS 100, Accounting 200 includes a series of video lectures accompanied by animated slides and problem sets with immediate feedback. Instead of meeting in a large lecture hall with 1,000 students three times a week, the instructor has developed these enhanced video based tutorials to teach accounting principles. Students meet eight times during the semester to listen to lectures from professors and business professionals who are involved in the accounting field. Students seem as satisfied with this course, as they do the traditional version and perform as well on exams as those in the traditional version of Accounting 200. On-campus students seem to enjoy the flexibility to learn at their own pace and convenience.

Physical Science 100, English 115, and Accounting 200, are being adapted for delivery to Independent Study students. This is another way the hybridization of education is taking place. Additionally, the CID is currently developing online courses for introductory Chemistry, American History, Biology, Book of Mormon, and Statistics. All of these courses are being developed for delivery on-campus and off campus using an interactive distance education model. The idea is to use multi-media and communication technology to create a rich context for student learning. An unintended consequence of the development of these courses is a lessening of the distinction between on- and off-campus courses, which is causing administration and faculty to rethink course delivery, support, and course prioritization, as well as issues of assessment, to name only a few. These online general education courses have been developed for on-campus delivery, and now are being developed for off-campus students. To offer these courses, however, Independent Study will need to adapt and adopt many practices associated with on-campus education.

\section{Independent Study Online}

The CID develops Independent Study university courses for online and paperbased delivery. Currently, these courses are exclusively transmissive and asynchronous designed for students to complete at their own pace. The online courses have multimedia enhancements, interactive exercises, and links to relevant information, giving students a richer learning experience. The CID is responsible for developing these courses while Independent Study (IS) markets them and provides support to students. The CID has developed over 70 university level online courses.

Another important element of CID's development of these courses is the intense effort by the CID and University administration to encourage academic

International Review of Research in Open and Distance Learning 
Bringing Online Learning to Campus: The Hybridization of Teaching and Learning at Brigham Young University

departments to assume more ownership over their Independent Study courses. To this end, instructional designers are assigned to Colleges and Departments and Deans and Chairs have been asked to prioritize and select courses for development. The shift in the control and responsibility of online courses from instructional designers or administrators into the hands of academic units is an important outcome of bringing course development to campus. Departments are beginning to see their Independent Study courses in the same light as their on-campus offerings. Ownership by academic departments and lessening the distinction between on- and off-campus students is central to the hybridization experience at BYU. Since1998, when President Bateman announced his support of web-based distance education, enrollments have grown from 7,000 to 46,000.

\section{Special Technology Projects}

In addition to the development of large general education courses, the CID develops technology projects for the improvement of education on-campus. To participate in the development of these projects, faculty members think of ways they could use technology to more effectively teach a particular concept or set of concepts. With the assistance of a trained instructional designer, the faculty member develops a proposal and submits it to the Committee for Instructional Media Arts (CIMA). If the University committee funds the project, the CID provides instructional design, art, programming, and evaluation support to develop and implement the project. For example, a chemistry professor saw the potential of interactive technology to help beginning chemistry students explore chemical principles. The difficulty with teaching introductory chemistry is chemistry students often "cookbook" by following lab instructions by rote, instead of engaging in problem solving and exploration. The virtual chemistry lab (ChemLab) was developed to encourage problem solving and exploration. These and many other special technology projects help improve the quality of education and engage faculty in thinking creatively about the ways in which technology can help solve particular instructional problems.

Semester Online, Independent Study, and Special Technology Projects are combined to serve multiple functions and hybridize education for on- and off campus students. For example, the CID is developing a large General Education course for introductory chemistry that will now include the recently developed virtual chemistry lab as an important component. The Physical Science 100 course is not only available for on-campus students, but is now being used by off-campus students, and many of the learning objects are being used by the faculty in the classroom. Additionally, a video introduction developed as a special technology project is being used in conjunction with English 115, to train students in the basic composition course about principles of research and how to best use library resources. The CID enhanced the Independent Study web-based courses that are now offered to Semester Online on-campus students, and on-

International Review of Research in Open and Distance Learning 
Bringing Online Learning to Campus: The Hybridization of Teaching and Learning at Brigham Young University

line courses developed for on-campus students are being adapted for off-campus delivery. These are all examples of hybridization in education at BYU.

The hybridization of education at BYU is emergent and ongoing, and is a result of multiple forces including administrative support, development of new organizational units, technological advances, the relationship between BYU and its sponsoring institution - the Church of Jesus Christ of Latter-day Saints. Many more administrative, curricular, and institutional decisions will further affect the hybridization of education at BYU. For example, from this chronology it is clear that distance education practices have been brought to campus and are hybridizing teaching and learning in this context. What has not happened, for the most part, is the exportation of campus teaching practices to Independent Study. Practices such as teacher-student interaction, student-to-student interaction, comprehensive student services, and informal support networks to name only a few, have not been adopted for off-campus delivery. Currently, these courses are largely asynchronous and transmissive. However, university administrators and faculty members are interested in bringing more interactive practices to distance learning. As faculty members have become more involved in the design and development of campus-based courses, they have begun to become more interested in developing more interactive courses for distance education students.

\section{Consequences of the Hybridization Experience}

Convergence of campus and distance education has influenced BYU administrative services, course and curriculum design, institutional goals and structures, resource sharing and collaboration, assessment, faculty and student roles, student services, and academic policies. As Universities manage this convergence process, we believe these key elements must be given careful attention.

\section{Administrative Support and Structure}

The support provided by President Bateman and other academic administrators was crucial for facilitating change and collaboration among university organizations. This support was realized in the development of new organizational units such as the Center for Instructional Design and the reorganization of administrative structures and reporting lines. For example, by bringing distance education under the direction of the Academic Vice President rather than a separate distance education administration, boundaries between on- and offcampus education were lessened. This change in administrative structure has been important for fostering collaboration and coordination between continuing education and campus. In addition, because distance education reports to 
Bringing Online Learning to Campus: The Hybridization of Teaching and Learning at Brigham Young University

academic administration, faculty's interests and concerns are more likely to be addressed. As distance and campus education converge, it is important that faculty members are involved in the decision making process and that academic administration are supportive of the convergence process.

\section{Course and Curriculum Design}

Another consequence of the hybridization experience is an increased level of attention to the instructional design of courses intended for campus and distance students. A greater focus on instructional design issues at the course level has led to greater attention to curriculum design within academic departments. In particular, as departments design and develop web-based courses for delivery to both on-campus and distance students, they must specify the course objectives and the best methods for teaching the course. This careful questioning of instructional objectives naturally leads to departments questioning and refining the design of their curriculum. For example, as a result of the development of several hybrid online courses, the BYU School of Religion has developed a strategic plan to use online education for their campus and distance students. During the process of writing this document, they refined their goals for religious education curriculum more generally. Similarly, the dean of General Education (GE) is conducting an extensive evaluation of online GE courses; this review is resulting in overall curriculum assessment and the refinement of course and curricular goals. This process of reflection and refinement of course and curriculum goals is an important consequence of the hybridization experience at BYU.

\section{Institutional Goals and Structures}

BYU is unique in that the goal to provide the "BYU experience" to students unites both on-campus and distance education efforts. BYU Independent Study courses have focused on a transmissive model to increase the efficiency and reach of their courses. In contrast, on-campus courses are based on interaction between a teacher and students. Although BYU has many large lecture courses, there is a concerted effort and commitment by faculty and administrators to provide students with a high quality mentored learning environment. As distance education practices and technologies were brought to campus, this tension between efficiency and quality was clearly manifest. For example, there is a debate among faculty and administrators about the extent to which online courses and distance education practices can provide students with the "BYU experience." One result of this debate is the development of a Teaching and Learning Support Services (TLSS) committee with members from the Testing Center, Independent Study, the Center for Instructional Design, the Faculty Center, the Lee Library, and the Office of Information Technology. This committee is 
Bringing Online Learning to Campus: The Hybridization of Teaching and

providing direction and coordination as the hybridization experience at BYU continues.

\section{Resource Sharing and Collaboration}

Another consequence of the hybridization experience is the increased collaboration and synergy between units that focus on "campus education" and those that focus on distance education." This sharing and collaboration has been one of the most important and interesting consequences of the hybridization of distance education at BYU. For example, there have been important discussions between technical staff, University administrators, instructional designers, the testing center, the library, and faculty members concerning the formulation of a written strategic plan for providing high quality and efficient education to students and supporting faculty in this endeavor. In addition, a committee comprised of members from Independent Study, the Testing Center, and the Center for Instructional Design, has developed a list of functional specifications for an enterprise wide assessment system for teaching on- and off campus students. Developing these specifications took collaboration and cooperation. Perhaps the most important ingredient of this successful collaboration was the blurring of boundaries between on and off campus teaching and learning.

\section{Assessment}

Assessment is an important issue associated with BYU's hybridization experience. As on-campus and distance education converges there is a need for a shared strategy for providing testing and assessment services to students. As mentioned previously, a committee with representatives from the Testing Center, Independent Study, and the Center for Instructional Design, has recently met to create an overall assessment plan that will include creating and delivering online tests and the ability to report and record grades for both campus and distance students. Additionally, the specifications included the ability to compare and analyze test scores and grades for distance and campus students. Currently, instructors teaching traditional courses, campus online courses, and independent study courses are required to access three different systems with little ability to compare test performance. The convergence of campus and distance education assessment practices and technologies will improve the quality of assessment and learning for all students taking BYU courses. 
Bringing Online Learning to Campus: The Hybridization of Teaching and Learning at Brigham Young University

\section{Changing Faculty and Student Roles}

The change in faculty and student roles is another important consequence of the hybridization experience. At BYU, many faculty members are developing a vision of the possibilities concerning how to redesign their campus courses for delivery to geographically remote students. Indeed, because distance education practices have been brought to campus, many faculty members are seeing the advantages and possibilities of using technology to teach students, whether they live on or off campus. However, teaching students in the context of hybrid courses often means that the instructor becomes de-centered. They become a guide and mentor, rather than the center of the instructional relationship. Learning to be successful in this new role requires training, practice, and support. At BYU, we are developing a faculty fellowship program in which faculty are selected and are given comprehensive training and support to learn to teach within the emerging hybrid model.

We have seen a similar shift in student roles. Campus students who take online courses identify flexibility as one of the major strengths of these courses. However, this flexibility requires that students pace themselves and seek additional help when necessary. Many students are not well equipped to learn independently and struggle when given flexibility. It is important that students are made aware of the new learner role they must adopt in hybrid courses. BYU developed a tutorial for on-campus semester online students to provide information about their role in these hybrid courses. Prior to the development of this tutorial, we interviewed 20 students who had dropped a hybrid campus course that not only required them to complete most of their course work online, but also required occasional meetings. From these interviews, we found that half of the students dropped the course because they thought the course was online and were unhappy that they were required to attend an occasional class meeting. The other half dropped the course because the course was online and they felt they could not take responsibility for their own learning and that they did not meet often enough. Providing students with the information about their student roles and the support they need to be successful is important to the success of the hybridization of education. It is likely that as courses intended for geographically remote students become more interactive, many of the students accustomed to a more transmissive model will need training to be successful in adopting this new student role.

\section{Student Services}

Providing student services for campus and distance students is another important issue raised by the hybridization experience. These student services include access to library, academic counseling, and financial-aid, tutoring services, to 
Bringing Online Learning to Campus: The Hybridization of Teaching and Learning at Brigham Young University

name only a few. As distance and campus education converges, the question of how to provide these services needs to be re-thought. Currently, BYU has comprehensive services for on-campus students, yet it has done little to provide similar value added services to distance students. As distance and on-campus education continues to converge, it is likely that providing student services for all students will become a priority.

\section{Academic Policies}

Many policy-related questions have yet to be addressed. For example, should there be a limit to the number of distance education courses a campus student can take? How many online courses can a student take if they are matriculated at BYU? How does one deal with copyright and intellectual property issues for faculty? How does faculty participation in designing and delivering these courses count towards promotion and tenure? These are important policy questions for students and faculty that become more salient as distance and campus education converge.

\section{Conclusion}

The hybridization experience is ongoing and complex. Important decisions have yet to be made about the ways in which distance education practices can provide students with the "BYU experience." Indeed, the search for better ways to serve the growing population of the Church of Jesus Christ of Latter-day Saints continues to provide intensity and direction to the hybridization experience at BYU. The convergence of distance education and on-campus education at BYU is embedded within the history of the mission and purpose of the campus. The mission of the University is to provide students with a spiritually enriched secular education. Due to the increase in Church membership and the cap on student enrollment, there has been a great deal of effort to find ways to provide the BYU experience to more people. This basic desire has required the administrative organization of online education for on-campus and off-campus students, coordination of services, deployment of technologies for on and offcampus education, rethinking of course prioritization, and strained the campus technology infrastructure. All of these efforts have led to a hybridization of education where the distinction between traditional and non-traditional students is becoming more blurred. As this case study demonstrates, this hybridization experience has brought distance education to the campus. But, campus practices have yet to be brought to distance education. The next phase in the hybridization experience of education at BYU will include the development and implementation of a distributed learning strategy for students regardless of their enrollment status or location.

International Review of Research in Open and Distance Learning 
Bringing Online Learning to Campus: The Hybridization of Teaching and Learning at Brigham Young University

\section{References}

Arvan, L., Ory, J., Bullock, C., Burnaska, K., Hanson, M. (September 1998). The SCALE Efficiency Projects. JALN, 2 (2), 33-60.

Bateman, M. (August, 1998). University conference address given to campus faculty and staff. Provo Utah: Brigham Young University.

Bourne, J. R. (September 1998). Net-Learning: Strategies for On-Campus and Off Campus Network-enabled Learning. JALN, 2 (2), 70-88.

Brigham Young University: Aims of a BYU Education. [Online]. Available at: http:// www.byu.edu/about/aims/.

Calder, J. (June 2000). Beauty Lies in the Eye of the Beholder. International Review of Research in Open and Distance Learning, 1 (1), [Online]. Available at: http:// www.irrodl.org/content/v1.1/judith.pdf.

Calvert, J. (January 2001). Deakin University: Going Online at a Dual Mode University. International Review of Research in Open and Distance Learning, 1 (2) [Online]. Available at: http: //www.irrodl.org/content/v1.2/ deakin.html.

Cookson, Peter (July 2001). Editorial: Global Diversity of Distance Education. International Review of Research in Open and Distance Learning, 2 (1) [Online]. Available at: http:// www.irrodl.org/content/v2.1/ editorial.html.

Feenberg, A. (1999). Distance Learning: Promise or Threat? [Online]. Available at: http:// www-rohan.sdsu.edu/faculty/ feenberg/TELE3.HTM.

Henstrom, R.H., and Oakes, K.R. (2001). The world is our campus: The history of the Division of Continuing Education at Brigham Young University.

Hiltz, S.R. (1998). Collaborative learning environments in asynchronous learning networks: Building learning communities. Unpublished manuscript.

Garrison, R. (June 2000). Theoretical Challenges for Distance Education in the 21st Century: A shift from Structural to Transactional Issues. International Review of Research in Open and Distance Learning, 1 (1). Available at: http:// www.irrodl.org/content/v1.1/ randy.pdf.

Levin, J.A., Levin, S.R, and Waddoups, G.L. (1999). Multiplicity in learning and teaching: A framework for developing innovative online education. Journal of Research on Computing in Education, 32 (2), 256-269.

Maitland, C., Hendrickson, R., Pena, D., \& Mitchell, D. (1998). Distance Education in Higher Education Institutions. Update, 4 (1) [Online]. Available at: http:// www.nea.org/he/heupdate/ vol4nol.pdf.

International Review of Research in Open and Distance Learning 
Bringing Online Learning to Campus: The Hybridization of Teaching and

Merriam. S.B. (1988). Case study research in education: A qualitative approach. San Francisco: Jossey-Bass.

NEA Higher Education Research Center (2000, April). Distance education at post-secondary institutions: 1997-1998.

Noble, D. (1997). Digital diploma mills: The automation of higher education. First Monday, 3 (1), 1-16.

Peters, O. (June 2000). Digital Learning Environments: New Possibilities and Opportunities. International Review of Research in Open and Distance Learning, 1 (1). Available at: http:// www.irrodl.org/content/ v1.1/otto.pdf.

Richards, L. A. (January 1997). What I Now Believe About a BYU Education That I Wish I Had Believed When I First Came [Online]. Available at: http:// speeches.byu.edu.devo/96-97/ RichardsW97.html

Rossman, M. H. (November 1999). Successful Online Teaching Using An Asynchronous Learner Discussion Forum. JALN, 3 (2), 91-97.

Stake, R. (1988). Case study methods in educational research: Seeing sweet water. In R.M. Yaeger (Ed.), Complimentary methods for research in education (253-278). Washington, DC: American Education Research Association.

Trindade, A. Rocha, C., Hermano, A. and Bidarra, J. (June 2000). Current Developmentsand Best Practice in Open and Distance Learning. International Review of Research in Open and Distance Learning, 1 (1). Available at: http:// www.irrodl.org/content/v1.1/ carmo_et_al.pdf.

Tait, A., and Mills, R. (Eds.). (1999). The Convergence of Distance and Conventional Education: Patterns of Flexibility for the Individual Learner. New York: Routledge.

Turoff, M. (1997). Alternative Futures for Distance Learning: The Force and the Darkside. [Online]. Available at: http://www.westa.edu/ distance/ turoff11.html.

Wang, C.X., Kanfer, A., Hinn, M.D., and Arvin, L. (2001). Stretching the boundaries: Using ALN to reach on-campus students during an off-campus summer session. Journal of Asynchronous Learning Networks 5 (1), pp.1-20.

Wegerif, R. (1998). The social dimension of asynchronous learning networks. Journal of Asynchronous Learning Networks 2 (1), 34-49.

Williams, R. (1961). The Long Revolution. England: Hazel Watson \& Viney Ltd. Aylesbury and Slough.

Yin, R. K. (1984). Case study research: Design and methods. Newbury Park, CA: Sage.

International Review of Research in Open and Distance Learning 
Bringing Online Learning to Campus: The Hybridization of Teaching and Learning at Brigham Young University

Citation Format

Waddoups, Gregory L. \& Howell, Scott L. (January, 2002) Bringing Online Learning to Campus: The Hybridization of Teaching and Learning at Brigham Young University.

International Review of Research in Open and Distance Learning: 2, 2 .

http://www.icaap.org/iuicode?149.2.2.5 